УДК 332.122:379.84

Дащук Ю.С., к.е.н., старший викладач

Луцький національний технічний університет

\title{
МЕТОДИКА ОЦІНКИ РІВНЯ РОЗВИТКУ РЕКРЕАЦІЙНОГО ПОТЕНЦІАЛУ РЕГІОНУ: ТЕОРЕТИЧНИЙ АСПЕКТ
}

У статті проведено огляд існуючих методик оцінки рекреаційного потенціалу, проаналізовано їх переваги та недоліки. Запропоновано власну методику, яка базується на розрахунку інтегрального показника рівня розвитку рекреаційного потенціалу регіону. Представлено систему показників та індексів для здійснення обрахунків по кожній із структурних компонент рекреаційного потенціалу. рекреація.

Ключові слова: рекреаційний потенціал, регіон, туризм, методика оцінки, туристичні ресурси,

Дащук Ю.Е

\section{МЕТОДИКА ОЦЕНКИ УРОВНЯ РАЗВИТИЯ РЕКРЕАЦИОННОГО ПОТЕНЦИАЛА РЕГИОНА: ТЕОРЕТИЧЕСКИЙ АСПЕКТ}

В статье проведен обзор существующих методик оценки рекреационного потенциала, проанализированы их преимущества и недостатки. Предложено собственную методику, которая базируется на расчете интегрального показателя уровня развития рекреационного потенциала региона. Представлена система показателей и индексов для осуществления вычислений по каждой из структурных компонентов рекреационного потенциала.

Ключевые слова: рекреационный потенциал, регион, туризм, методика оценки, туристические ресурсы, рекреация.

Dashchuk Yu.

\section{METHOD OF EVALUATION OF THE LEVEL OF REGION RECREATION POTENTIAL DEVELOPMENT: THEORETICAL ASPECTS}

The article reviews the existing methods of estimating recreational potential, analyzes their advantages and disadvantages. Proposed own methodology, which is based on the calculation of the integral indicator of the level of recreational potential development in the region. The system of indicators and indices for the calculation of each of the structural components of the recreational potential is presented.

Key words: recreational potential, region, tourism, estimation methodology, tourist resources, recreation.

Постановка проблеми у загальному вигляді i iï зв'язок 3 важливими науковими та практичними завданнями. В сучасних умовах посилення конкуренції між територіальними об'єднаннями, містами і регіонами все більшої уваги і значення набуває можливість аналітичного обгрунтування їх потенціалу у різних сферах господарював. Не виключенням $є$ й рекреаційна сфера регіону, оцінка потенціалу якої $\epsilon$ важливою для різних суб'єктів господарювання, зокрема:

- для інвесторів - 3 точки зору виявлення основних передумов ведення рекреаційного бізнесу в регіоні, зацікавленості органів влади у здійсненні рекреаційної діяльності;

- для різноманітних фондів, об’єднань - слугує базисом для обгрунтування необхідності надання фінансової допомоги регіону, його пріоритетності щодо участі в певних програмах тощо;

- для органів влади різних рівнів - дає змогу визначити ключові напрямки розвитку рекреаційної сфери регіону і шляхи їх нарощення; 
- для рекреантів - виступає джерелом інформації про цікаві та атрактивні рекреаційні продукти регіону.

Аналіз останніх досліджень, у яких започатковано вирішення проблеми. Сучасна наукова думка характеризується численними теоретичними, методичними та практичними дослідженнями, щодо рекреаційної сфери та особливостей використання іiі потенціалу. Науковцями, які присвятили свої роботи питанню оцінки рекреаційного потенціалу (РП) регіону, є: Бейдик О. О., Бендзюк В. Д., Бережна I. В., Герасимчук 3. В., Глядіна М. В., Гудзь М. В., Давиденко І. В., Зелінський І., Кифяк В. Ф., Коленда Н. В., Мацола В. І., Самко О. О., Стеченок Д. М., Черчик Л. М., Шабардіна Ю. В. та інші. Поряд 3 цим, питанню формування комплексного підходу до оцінки РП регіону та розробки методичного інструментарію, щодо його забезпечення приділено недостатньо уваги.

Цілі статті. Метою статті є огляд найбільш суттєвих положень існуючих наукових праць, що стосуються рекреаційної сфери й формування на цій основі авторської методики оцінки рівня розвитку РП регіону.

\section{Виклад основного матеріалу дослідження 3 повним обгрунтуванням отриманих наукових результатів}

Комплексне дослідження рівня розвитку РП здійснюється для прогнозування майбутніх тенденцій його становлення та пошуку механізмів управління на регіональному рівні, які б відповідали засадам стійкості. Основними завданнями аналітичного дослідження є:

- розгляд існуючих методик оцінки рівня розвитку РП та суміжних до нього видів потенціалу на регіональному рівні, проведення критичного аналізу щодо них;

- формування авторської методики оцінки рівня розвитку РП регіону з врахуванням результатів теоретичного блоку досліджень та найбільш суттєвих положень існуючих наукових праць в рамках зазначеної проблематики;

- доведення методики до широкого кола суб’єктів, з обгрунтуванням ії̈ практичного застосування.

В межах даного дослідження особливий інтерес становлять роботи, які стосуються розгляду РП саме на регіональному рівні. Так, Шабардіна Ю. В. інтегральну оцінку рекреаційного потенціалу пропонує проводити через призму двох складових, а саме [1, c. 39]:

- рекреаційну активність, зокрема 3 позиції показників активності щодо задоволення рекреаційних потреб в оздоровленні й відпочинку, в послугах закладів культури, в туристичних послугах;

- власне рекреаційний потенціал, зокрема шляхом оцінки історико-культурної спадщини, природно-рекреаційних, інфраструктурних, інноваційно-інвестиційних ресурсів, стану навколишнього природного середовища.

При цьому автором не виокремлюються фінансові ресурси як джерело формування РП регіону. Щодо розрахунку рекреаційної активності, який за методикою автора повинен здійснюватися відносно наявного населення, то, на наш погляд, це не зовсім вірно, адже задоволення рекреаційних потреб має враховувати й рекреантів, які відвідують регіон.

Досить цікавим та принципово новим є науковий підхід Бережної I. В, згідно з яким потенціал оцінюється як з позиції споживача рекреаційних ресурсів, так і з позиції виробника рекреаційних послуг при максимальному врахуванні інтересів всіх зацікавлених сторін [2, с. 115]. Підтримуємо позицію автора стосовно врахування інтересів усіх зацікавлених сторін, проте вважаємо за необхідне дещо іiі доповнити. Зокрема, доцільним, на наш погляд, в процесі оцінки РП регіону $\epsilon$ розгляд результативності діяльності територіальної та галузевої груп стейкхолдерів. Це дозволить виявити недоліки у їх роботі, розробити механізми для її активізації шляхом 
врегулювання інтересів зацікавлених сторін, а також слугуватиме аналітичним базисом для налагодження взаємозв'язків між ними в рамках розвитку РП регіону.

Черчик Л. М., Коленда Н. В. [3, с. 65], досліджуючи стратегічний потенціал рекреаційної системи регіону, пропонують для його оцінки використовувати п'ять груп показників, які характеризують природно-рекреаційну, фінансову, інфраструктурну, трудову та екологічну компоненти. На основі отриманих результатів авторами здійснено прогнозування потенціалу за допомогою графоаналітичної моделі, зокрема «шестигранника». В цілому, даний підхід може бути використаний і в рамках оцінки РП регіону, проте представлені авторами в рамках методики групи показників характеризують у значній мірі лише ресурсну складову потенціалу, що є дещо спрощеним підходом до його оцінки. На нашу думку, визначення рівня розвитку РП регіону має охоплювати дещо ширше коло показників, серед яких: результативність діяльності зацікавлених сторін, рівень конкурентних переваг регіону та його рекреаційної галузі. Запропоновані напрями дослідження РП регіону поряд із ресурсним забезпеченням посідають, на наш погляд, не менш важливе значення в процесі його оцінки на регіональному рівні.

Гудзь М. В., досліджуючи потенціал курортно-рекреаційних територій, використовувала для оцінки кваліметричний підхід, який дозволив встановити реальну ринкову вагу складових потенціалу курортно-рекреаційної території у створенні рекреаційного продукту, визначити елементів-лідерів та аутсайдерів, ефективно розвивати рекреаційну діяльність з випередження купівельних уподобань та запитів [4]. 3 позиції нашого дослідження такий підхід може застосовуватися в рамках виокремлення етапів нарощення структурних компонентів РП регіону, оскільки дозволить сформувати якісний рекреаційний продукт та забезпечить ефективний розвиток РП регіону.

У дослідженнях Давиденка I. В. [5, с. 48] рекреаційно-туристичний потенціал визначається як потенціал усіх ресурсів, що не тільки задовольняють біологічні (психофізіологічні) i соціальні (духовно-інтелектуальні) потреби людей, але й представляють собою ресурсний потенціал відповідної економічної діяльності регіону. Це свідчить про те, що автор є прихильником ресурсного підходу до дослідження потенціалу. Погоджуємося з необхідністю врахування ресурсів в процесі оцінки РП регіону, проте в сучасних умовах інформатизації суспільства РП визначається також промоактивністю регіону стосовно представлення своїх рекреаційних переваг. Обгрунтована та правильно побудована регіональна маркетингова політика слугує вагомим джерелом нарощення РП регіону, а тому має враховуватися в процесі його оцінки.

Стеченко Д. М. пропонує рекреаційний потенціал вивчати у два етапи. На першому етапі пропонує виділити рекреаційний потенціал території (РПТ) як єдине ціле і визначити його територіальні межі. В план такого дослідження вводяться лише ті компоненти природи і культурно-історичні об'єкти, які використовуються або можуть використатися в рекреаційних цілях. На другому етапі пропонує аналізувати компонентну структуру РПТ, зокрема природні і культурно-історичні рекреаційні ресурси з погляду розвитку різних видів рекреації та їх ролі в структурі господарства регіону [6, с. 70]. Такий підхід, на наш погляд, є достатньо грунтовним, проте він не передбачає оцінки іміджу регіону, результативності діяльності стейкхолдерів як вагомих напрямків формування РП регіону.

Один з варіантів методики оцінки природного рекреаційно-ресурсного потенціалу навів Бейдик О. О. [7, с. 47-79 ]. Дослідження зводяться до оцінки широкого спектру ресурсів та подані у розрізі областей і АР Крим.

Самко О. О. пропонує здійснювати оцінку туристичного потенціалу за допомогою інтегрального методу через оцінку інфраструктурної, інформаційної, інтелектуальної, культурно-історичної, інформаційної складових [8, с. 130]. Погоджуємося із можливістю 
застосування інтегрального методу для оцінки туристичного потенціалу, але вихідні дані, які застосовуються автором для оцінки, на наш погляд, потребують подальшого обгрунтування та вдосконалення.

Кифяк В. Ф. [9], вивчаючи розвиток територіальних рекреаційних систем, виділяє ряд показників, серед яких: обсяг наданих послуг, кількість осіб, яким надавались характерні та супутні послуги, експорт та імпорт рекреаційних послуг, зайнятість у рекреаційній сфері, надходження до бюджетів усіх рівнів тощо. Вважаємо, що ряд із представлених показників можуть бути використані у процесі оцінки структурних компонентів РП регіону.

Загалом, більшість публікацій, представлених у науковій літературі, щодо визначення рівня розвитку РП, мають сегментарний характер, тобто зосереджують увагу лише на окремих компонентах потенціалу, найчастіше на ресурсній. Поряд 3 цим, розгляду результативності стейкхолдерів, а також дослідженню іміджу регіону, його промоактивності в рамках оцінки РП регіону приділено недостатньо уваги. Цікавим для нас є дослідження конкурентних переваг регіону та його рекреаційної галузі, як основи формування РП регіону. Враховуючи проведений аналіз існуючих наукових підходів до оцінки рівня розвитку РП регіону, а також базуючись на результатах власних досліджень, ключовими напрямами методики оцінки рівня розвитку РП регіону, будуть:

- оцінка рекреаційних ресурсів регіону, які використовуються в процесі рекреаційної діяльності;

- оцінка конкурентних переваг регіону та його рекреаційної галузі задля ідентифікації унікальних їх характеристик, які слугуватимуть базисом для розвитку РП; - оцінка результативності територіальної та галузевої груп стейкхолдерів, діяльність яких визначає напрями та темпи розвитку РП регіону;

- оцінка промоактивності регіону та сформованості його рекреаційного іміджу, які слугують інструментом залучення рекреантів у регіоні, а отже формують його РП.

Структурну схему авторського методичного підходу до визначення рівня розвитку РП регіону наведено на рис. 1.1.

Так, на початковому етапі визначаємо мету, об'єкт, завдання оцінки, методи, які будуть застосовуватися в рамках дослідження. Зокрема, метою оцінки є дослідження рівня розвитку РП регіону, об’єктом аналітичного дослідження - регіон на предмет рівня розвитку його рекреаційного потенціалу.

В рамках попередніх досліджень нами виокремлено чотири структурні компоненти РП регіону. Інтерпретація їх на площину аналітичних досліджень дозволить оцінити рівень розвитку РП регіону. Так, залежно від змісту, який вкладається у тлумачення кожної із структурних компонент РП регіону, буде залежати вибір часткових показників для їх оцінки.

Згідно з першим підходом, РП розглядається з точки зору сукупності ресурсів та узагальнюється в рамках структурної компоненти «маю». В даному випадку мова йде про забезпеченість регіону ресурсами рекреаційного призначення, які можуть застосовуватися для виробництва рекреаційних продуктів та задоволення потреб рекреантів у оздоровленні та відпочинку. Так, основними групами ресурсів, які в рамках структурної компоненти «маю», на наш погляд, є: природні рекреаційні, матеріально-технічні, історико-культурні, трудові та фінансові ресурси. 


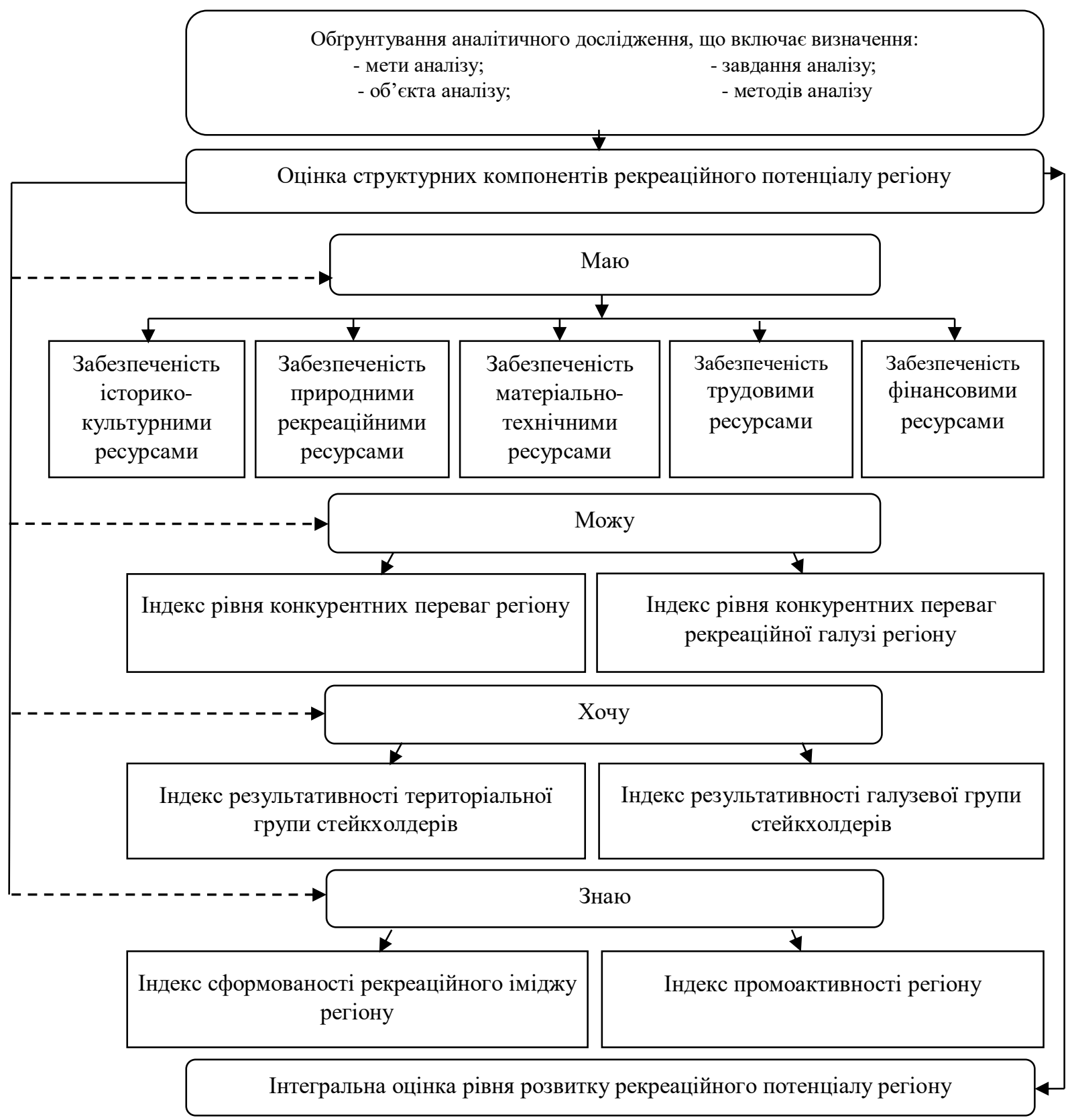

Рис. 1.1. Алгоритм методики оцінки рівня розвитку рекреаційного потенціалу регіону*

* сформовано автором

Для здійснення комплексної оцінки структурної компоненти «маю» пропонується розрахувати п'ять групових індексів, кожен з яких характеризує забезпеченість регіону певним видом ресурсів. Розрахунок кожного із вищевказаних індексів вважаємо за необхідне здійснювати за допомогою системи часткових показників, які представлені у табл. 1.1. 
Система показників для розрахунку рівня розвитку структурної компоненти «маю»*

\begin{tabular}{|c|c|}
\hline Груповий індекс & Часткові показники \\
\hline 1 & 2 \\
\hline \multirow{6}{*}{$\begin{array}{c}\text { Індекс } \\
\text { забезпеченості } \\
\text { природними } \\
\text { рекреаційними } \\
\text { ресурсами }\end{array}$} & - забезпеченість регіону лісовими ресурсами, \%; \\
\hline & - забезпеченість землями природно-заповідного фонду, \%; \\
\hline & - забезпеченість регіону гідроресурсами, \%; \\
\hline & - забезпеченість регіону мінеральними водами, куб.м/добу/люд.; \\
\hline & - забезпеченість регіону лікувальними грязями, куб.м/люд.; \\
\hline & - забезпеченість землями рекреаційного призначення, \%; \\
\hline \multirow{6}{*}{$\begin{array}{c}\text { Індекс } \\
\text { забезпеченості } \\
\text { історико- } \\
\text { культурними } \\
\text { ресурсами }\end{array}$} & - кількість пам’яток археології, історії, монументального мистецтва, од.; \\
\hline & $\begin{array}{l}\text { - кількість пам’яток архітектури та містобудування, садово-паркового мистецтва, } \\
\text { науки і техніки, ландшафтів, од.; }\end{array}$ \\
\hline & $\begin{array}{l}\text { - кількість закладів культури та мистецтва (клубних закладів, музеїв, театрів, } \\
\text { бібліотек, демонстраторів фільмів), од./10 тис. населення; }\end{array}$ \\
\hline & - кількість сакральних споруд у регіоні, од.; \\
\hline & $\begin{array}{l}\text { - місткість закладів культури та мистецтва (театрів, клубних закладів, } \\
\text { демонстраторів фільмів), місць/10 тис. населення; }\end{array}$ \\
\hline & - частка рекреаційної площі у загальній структурі музейної території, \%; \\
\hline \multirow{11}{*}{$\begin{array}{c}\text { Індекс } \\
\text { забезпеченості } \\
\text { матеріально- } \\
\text { технічними } \\
\text { ресурсами }\end{array}$} & - кількість готелів та аналогічних засобів розміщення, од.; \\
\hline & - місткість готелів та аналогічних засобів розміщення, місць / 10 тис. населення; \\
\hline & - кількість спеціалізованих засобів розміщення, од.; \\
\hline & - місткість спеціалізованих засобів розміщення, місць /10 тис. населення; \\
\hline & - кількість об’єктів ресторанного господарства, од.; \\
\hline & - місткість об’єктів ресторанного господарства, місць/10 тис. населення; \\
\hline & - щільність залізничних колій загального користування, \\
\hline & $\begin{array}{l}\text { - щільність автомобільних доріг загального користування з твердим покриттям, } \\
\text { км/1000 км²; }\end{array}$ \\
\hline & - кількість аеропортів, морських та річкових портів, од.; \\
\hline & - доступність користування мобільним зв’язком, \%; \\
\hline & - доступність користування мережею Інтернет, \%; \\
\hline \multirow{5}{*}{$\begin{array}{c}\text { Індекс } \\
\text { забезпеченості } \\
\text { трудовими } \\
\text { ресурсами }\end{array}$} & $\begin{array}{l}\text { - кількість працівників зайнятих у культурно-мистецькій сфері (театри, клубні } \\
\text { заклади, музеї, виставкові заклади), осіб/10 тис. населення; }\end{array}$ \\
\hline & $\begin{array}{l}\text { - кількість зайнятого населення у суб’єктів туристичної діяльності (туроператори, } \\
\text { турагенти, екскурсоводи), осіб /10 тис. населення; }\end{array}$ \\
\hline & $\begin{array}{l}\text { - кількість працівників готелів та аналогічних засобів розміщення, осіб /10 тис. } \\
\text { населення; }\end{array}$ \\
\hline & $\begin{array}{l}\text { - кількість працівників у спеціалізованих засобах розміщення, осіб /10 тис. } \\
\text { населення; }\end{array}$ \\
\hline & - частка працівників рекреації у загальній чисельності працівників ПЗФ, \%; \\
\hline \multirow{2}{*}{$\begin{array}{c}\text { Індекс } \\
\text { забезпеченості } \\
\text { фінансовими } \\
\text { ресурсами }\end{array}$} & - інвестиції в основний капітал діяльності готелів та ресторанів, тис. грн.; \\
\hline & - інвестиції в основний капітал діяльності у сфері культури і спорту, тис. грн. \\
\hline
\end{tabular}

Враховуючи ситуацію, за якої часткові показники мають різну систему вимірників, необхідним є здійснення їх стандартизації, елімінування одиниць виміру, що дозволить згрупувати й систематизувати їх для розрахунку значення групових індексів. Зазначимо, що усі показники повинні бути приведені у діапазоні [0;1]. Стандартизацію часткових показників пропонуємо здійснювати на основі варіаційного розмаху за формулою: 


$$
X_{i j}=\frac{a_{i j}}{a_{i j_{\max }}},
$$

де $X_{i j}$ - стандартизований j-ий показник i-го регіону;

$a_{i j}$ - фактичне значення j-того показника для i-го регіону;

$a_{i j_{\max }}$ - максимальне значенння j-того показника для i-го регіону.

Групові індекси забезпеченості регіону певним видом ресурсів пропонуємо розраховувати за формулою:

$$
I_{i j}=\frac{1}{n} \sum_{j=1}^{n} X_{i j}, i=\overline{1, m},
$$

де $X_{i j}$ - стандартизований ј-ий показник і-го регіону;

$I_{i j}$ - груповий індекс забезпеченості ј-тим видом ресурсів і-го регіону.

Здійснивши вищевикладені математичні перетворення, обчислимо рівень розвитку структурної компоненти «маю» РП регіону за формулою:

$$
I_{\text {маю }}=\frac{1}{n} \sum_{j=1}^{n} I_{i j}, i=\overline{1, m},
$$

де $I_{\text {маю }}-$ індекс рівня розвитку структурної компоненти «маю»;

$I_{i j}$ - груповий індекс ј-го виду, який формує структурну компоненту «маю» i-го регіону.

Зазначимо, що запропонований підхід до стандартизації часткових показників, розрахунку групових індексів та обчислення рівня розвитку структурних компонентів пропонуємо застосовувати й в подальших розрахунках в рамках даної статті.

Наступним підходом до розгляду РП регіону $є$ його представлення 3 позиції можливостей, що систематизовано в рамках структурної компоненти «можу». Її оцінку здійснимо через розрахунок рівня конкурентних переваг регіону та рекреаційної галузі, яка в ньому функціонує. Систему показників для оцінки структурної компоненти «можу» РП регіону представлено у табл. 1.2.

\begin{tabular}{|c|c|}
\hline Групові індекси & Часткові показники \\
\hline \multirow{8}{*}{$\begin{array}{c}\text { Індекс рівня } \\
\text { конкурентних } \\
\text { переваг } \\
\text { рекреаційної галузі } \\
\text { регіону }\end{array}$} & $\begin{array}{l}\text { - частка регіону в загальній структурі забезпеченості держави природними } \\
\text { рекреаційними ресурсами,\%; }\end{array}$ \\
\hline & $\begin{array}{l}\text { - частка регіону в загальній структурі забезпеченості держави історико- } \\
\text { культурними ресурсами,\%; }\end{array}$ \\
\hline & $\begin{array}{l}\text { - частка регіону в загальній структурі забезпеченості держави матеріально- } \\
\text { технічними ресурсами,\%; }\end{array}$ \\
\hline & $\begin{array}{l}\text { - частка регіону в загальній структурі забезпеченості держави трудовими } \\
\text { ресурсами,\%; }\end{array}$ \\
\hline & $\begin{array}{l}\text { - частка регіону в загальній структурі забезпеченості держави фінансовими } \\
\text { ресурсами,\%; }\end{array}$ \\
\hline & - скидання забруднених вод у природні поверхневі водні об’єкти, млн. м³; \\
\hline & $\begin{array}{l}\text { - викиди забруднюючих речовин в атмосферне повітря від стаціонарних та } \\
\text { пересувних джерел забруднення, тис. т.; }\end{array}$ \\
\hline & - утворення відходів I-III класів небезпеки, тис. т./км²; \\
\hline $\begin{array}{l}\text { Індекс рівня } \\
\text { конкурентних } \\
\text { переваг регіону }\end{array}$ & $\begin{array}{l}\text { - оцінка конкурентних переваг регіону за соціально-економічними показниками, } \\
\text { балів }\end{array}$ \\
\hline
\end{tabular}

Таблиця 1.2

Система показників для розрахунку рівня розвитку структурної компоненти «можу»*

* сформовано автором 
Стандартизація часткових показників здійснюємо з використанням формули (1.1). Для розрахунку групових індексів, як і в попередніх розрахунках, застосовуємо формули (1.2). Рівень розвитку структурної компоненти «хочу» пропонуємо обчислювати за формулою (1.3).

Ще одним підходом до розуміння РП регіону є його представлення через синергетичний ефект від взаємодії стейкхолдерів. В даному випадку мова йде про структурну компоненту «хочу». Оцінку рівня ії розвитку пропонуємо здійснювати через аналіз результативності діяльності територіальної та галузевої груп стенйкхолдерів. Так, від ефективності їх роботи та досягнення домовленостей у процесі реалізації цілей рекреаційної діяльності залежать задоволення потреб рекреантів, формування нових рекреаційних продуктів й загалом конструктивний розвиток РП регіону. Вихідні дані для розрахунку структурної компоненти «хочу» РП регіону представлено в табл. 1.3.

Таблиця 1.3

Система показників для розрахунку рівня розвитку структурної компоненти «хочу»*

\begin{tabular}{|c|c|}
\hline Групові індекси & Часткові показники \\
\hline \multirow{6}{*}{$\begin{array}{c}\text { Індекс результативності } \\
\text { територіальної групи } \\
\text { стейкхолдерів }\end{array}$} & $\begin{array}{l}\text { - обсяг фінансових асигнувань для реалізації програм розвитку } \\
\text { рекреаційної сфери у регіоні, тис. грн.; }\end{array}$ \\
\hline & - витрати на утримання об’єктів ПЗФ, тис. грн.; \\
\hline & $\begin{array}{l}\text { - кількість функціонуючих туристичних маршрутів на об’єктах } \\
\text { ПЗФ, од.; }\end{array}$ \\
\hline & - рівень середньомісячної заробітної плати у регіоні, грн.; \\
\hline & - навантаження на одне робоче місце у регіоні, осіб; \\
\hline & $\begin{array}{l}\text { - кількість громадських організації в сфері розвитку туризму та } \\
\text { курортів, що діють в регіоні, од.; }\end{array}$ \\
\hline \multirow{10}{*}{$\begin{array}{c}\text { Індекс результативності } \\
\text { галузевої групи } \\
\text { стейкхолдерів }\end{array}$} & - кількість суб’єктів туристичної діяльності, од.; \\
\hline & - кількість організаторів виставок та виставкових центрів, од.; \\
\hline & $\begin{array}{l}\text { - кількість обслугованих у готелях та інших засобах розміщення, } \\
\text { осіб; }\end{array}$ \\
\hline & $\begin{array}{l}\text { - кількість обслугованих у спеціалізованих засобах розміщення, } \\
\text { осіб; }\end{array}$ \\
\hline & $\begin{array}{l}\text { - кількість туристів та екскурсантів, обслугованих туроператорами } \\
\text { та турагентами, осіб; }\end{array}$ \\
\hline & $\begin{array}{l}\text { - коефіцієнт використання місткості готелів та інших засобів } \\
\text { розміщення, \%; }\end{array}$ \\
\hline & $\begin{array}{l}\text { - коефіцієнт використання місткості спеціалізованих засобів } \\
\text { розміщення,\%; }\end{array}$ \\
\hline & $\begin{array}{l}\text { - доходи від діяльності готелів та інших засобів розміщення, тис. } \\
\text { грн.; }\end{array}$ \\
\hline & $\begin{array}{l}\text { - доходи від діяльності спеціалізованих засобів розміщення, тис. } \\
\text { грн.; }\end{array}$ \\
\hline & 'єктів туристичної діяльності, тис. грн. \\
\hline
\end{tabular}

* сформовано автором

Стандартизація часткових показників здійснюємо з використанням формули (1.1). Для розрахунку групових індексів, як і в попередніх розрахунках, застосовуємо формули (1.2). Рівень розвитку структурної компоненти «хочу» пропонуємо обчислювати за формулою (1.3).

I заключним підходом до розгляду РП регіону є його ідентифікація як певного нематеріального активу, що узагальнюється в рамках структурної компоненти «знаю». 3 позиції РП мова йде про імідж регіону та засоби, які сприяють поширенню позитивної суспільної думки про його рекреаційні можливості.

Для оцінки структурної компоненти «знаю» пропонується використовувати два показники: індекс сформованості рекреаційного іміджу регіону та індекс 
промоактивності регіону. Система показників для розрахунку останнього представлена в табл. 1.4.

Таблиця 1.4

Система показників для розрахунку індексу промоактивності регіону *

\begin{tabular}{|c|l|}
\hline Групові індекси & \multicolumn{1}{|c|}{ Часткові показники } \\
\hline \multirow{4}{*}{$\begin{array}{c}\text { Індекс } \\
\text { промоктивності } \\
\text { регіону }\end{array}$} & - частка туристичних агенцій, що мають власні сайти, од.; \\
\cline { 2 - 2 } & - кількість туристичних інформаційних центрів та пунктів у регіоні, од.; \\
\cline { 2 - 2 } & - кількість виставок, проведених в регіоні, од.; \\
\cline { 2 - 2 } & - кількість ярмарок, проведених в регіоні, од.; \\
\cline { 2 - 2 } & $\begin{array}{l}\text { - кількість івент-заходів у сфері туризму та курортів, запланованих у } \\
\text { регіоні, од. }\end{array}$ \\
\hline
\end{tabular}

* сформовано автором

Механізм стандартизації часткових показників, а також розрахунок групового індексу здійснюються відповідно за формулами (1.1) та (1.2).

Зупинимося більш детально на визначенні та обчисленні індексу сформованості іміджу регіону. Зауважимо, що в рамках дослідження імідж регіону розглядається 3 позиції визнання суспільством рекреаційної привабливості території. Мова йде не про загальний імідж регіону, а саме про позиціонування його з точки зору нематеріальних переваг для здійснення рекреаційної діяльності, а також про мотиви його відвідання з боку рекреантів, тобто про рекреаційний імідж регіону. Останній, на наш погляд, формується на основі певних напрямів, з врахуванням яких у людини формується певне ставлення до регіону та розуміння його рекреаційних можливостей.

Так, Кирюніним А. Е. $з$ метою визначення основних елементів іміджу регіону було проведено опитування людей більш ніж у 50 державах і містах світу [10]. Отримані результати свідчать, що регіони найчастіше асоціюються у людей 3 географічним положенням, культурою, народом, природою й історією. Виходячи з цього, науковцем було сформовано складові іміджу регіону, серед яких: географічна, культурна, етнічна, історична. На наш погляд, такий підхід може бути застосованим i до оцінки сформованості рекреаційного іміджу регіону. Спираючись на сформовані Кирюніним А. Е. складові іміджу регіону, а також на дослідження Саймона Анхольта щодо іміджевого індексу, беручи до уваги авторське бачення вирішення вказаної проблеми, пропонуємо наступні напрями формування рекреаційного іміджу регіону:

1. Історико-культурна привабливість

2. Івент-активність

3. Географічна доступність

4. Природна автентичність

5. Інфраструктурна зручність

Оцінка кожного із представлених напрямків дозволить виявити загальне бачення сформованості рекреаційного іміджу регіону. Найбільш доцільним методом оцінки рекреаційного іміджу регіону є проведення анкетування. Розрахувавши суму балів по кожному iз представлених напрямів його формування, поділену на кількість респондентів, зможемо отримати показник сформованості рекреаційного іміджу регіону. 3 цією метою розробимо шкалу оцінки рекреаційного іміджу регіону (табл. 1.5).

Для проведення оцінки розроблено анкети стосовно кожного із запропонованих напрямів формування рекреаційного іміджу регіону із системою запитань, кожне 3 яких оцінюється балом - від 1 до 5. Так, опитування запропоновано здійснювати серед широкого кола фахівців рекреаційного бізнесу, органів місцевого самоврядування та населення у різних регіонах. В подальшому залежно від кількості набраних балів в рамках анкетування здійснимо ранжування регіонів за рівнем сформованості рекреаційного іміджу. 
Таблиця 1.5

Шкала оцінки рекреаційного іміджу регіону*

\begin{tabular}{|c|c|}
\hline Характеристика іміджу & Бали \\
\hline Стійкий сформований імідж & $(4-5]$ \\
\hline Сформований імідж & $(3-4]$ \\
\hline Нестійкий імідж & $(2-3]$ \\
\hline Слабовиражений імідж & $(1-2]$ \\
\hline Відсутній імідж & $(0-1]$ \\
\hline
\end{tabular}

* сформовано автором на основі даних джерела: [11]

Таким чином, на основі розрахунку індексів промоактивності регіону та сформованості рекреаційного іміджу регіону, обчислимо рівень розвитку структурної компоненти «знаю» за формулою (1.3).

Виходячи 3 вищенаведеного, рівень розвитку РП регіону слід обчислювати на основі структурних компонентів, які його формують. Таким чином, інтегральний індекс рівня розвитку РП регіону пропонуємо розраховувати за формулою:

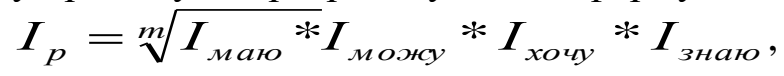

де $I_{p}$ - інтегральний індекс рівня розвитку РП і-го регіону;

$I_{\text {маю }}$ - індекс рівня розвитку структурної компоненти «маю» і-го регіону;

$I_{\text {можу }}$ - індекс рівня розвитку структурної компоненти «можу» і-го регіону;

$I_{\text {хочу }}$ - індекс рівня розвитку структурної компоненти «хочу» і-го регіону;

$I_{\text {знаю }}$ - індекс рівня розвитку структурної компоненти «знаю» і-го регіону;

Висновки. Таким чином, запропонований методичний підхід до визначення рівня розвитку РП дозволяє комплексно підійти до його оцінки шляхом аналізу рівня розвитку кожної із структурних компонентів РП регіону. При цьому застосування інтегрального оцінювання дозволяє розрахувати загальний рівень розвитку РП регіону, слугує передумовою для вибору шляхів ефективного використання та нарощення РП, що в підсумку сприяє інтенсифікації соціально-економічних процесів у регіоні.

\section{Список використаних джерел:}

1. Шабардіна Ю. В. Рекреаційний потенціал як складова продуктивних сил регіонального економічного простору : дис. канд. екон. наук : 08.00.05. / Ю. В. Шабардіна. - Чернігів, 2011. - 204 с.

2. Бережна I. В. Національні пріоритети та регіональні детермінанти соціально-економічного зростання (на матеріалах АР Крим) / І. В. Бережна; НАН України. Ін-т регіон. дослідж., 2004. - 640 с.

3. Черчик Л. М. Стратегічний потенціал рекреаційної системи регіону : теорія, методологія, оцінка : монографія / Л. М. Черчик, Н. В. Коленда. - Луцьк: ЛНТУ, 2008. - 235 с

4. Гудзь М. В. Потенціал приморської курортно-рекреаційної території: стан та перспективи використання : монографія / М. В. Гудзь. - Донецьк: Ін-т економіко-правових дослідж. НАН України : Юго-Восток, 2010. - 352 с.

5. Давиденко І. В. Організаційно-економічний механізм регулювання розвитку рекреаційної системи регіону : дис. канд. екон. наук: 08.02.03 / І. В. Давиденко. - Одеса : Одес. держ. екон. ун-т., 2006.

6. Стеченко Д. М. Теоретичні аспекти дослідження природно-рекреаційного потенціалу / Д. М. Стеченко, I. В. Безуглий // Науковий вісник ЧДІЕУ. - 2009. - № 2 (3). - С. 65-76.

7. Бейдик О. О. Рекреаційно-туристські ресурси України : методика та методологія аналізу, термінологія, районування / О. О. Бейдик. - К. : Вид.-поліграф. центр «Київський університет», 2001. - 395 с.

8. Самко О. О. Оцінка туристичного потенціалу регіону та рівня його використання / О. О. Самко // Економічні науки.

- Серія «Регіональна економіка» : зб. наук. пр. - Вип. 7 (27). - Ч. 4. - Луцьк, 2010. - С. 129-134.

9. Кифяк В. Ф. Стратегія розвитку територіальо рекреаційної системи : теорія, методологія, практика : монографія / В. Ф. Кифяк. - Київ; Чернівці : Книги-XXI, 2010. - 432 с.

10. Кирюнин А. Е. Имидж региона как интериоризация культуры / А. Е. Кирюнин. - М. : Книж. дом «Университет», 2000. $-267 \mathrm{c}$.

11. Драченко О. В. Формування системи маркетингу міста : дис. канд. екон. наук : 08.00.05 / О. В. Драченко. - Луцьк, 2011. - $193 \mathrm{c}$.

Рецензент д.е.н., професор Матвійчук Л.Ю. 